\title{
13
}

\section{Fragmented pragmatism: the conclusion and adoption of international treaties in Vietnam}

\author{
Tannetje Bryant and Brad Jessup
}

Although The Socialist Republic of Vietnam (hereafter 'Vietnam') has rules regarding the conclusion and adoption ${ }^{1}$ of international treaties, they do not make clear whether international obligations entered into by Vietnam are self-executing or require the passage of national legislation to become effective domestically. The resolution to this issue is important because the mode of adoption of international treaties determines which law to apply where there is a conflict between an international treaty obligation and a domestic law. The issue also indirectly relates to how Vietnam complies with its treaty obligations.

This chapter will examine the rules with regard to the conclusion and adoption of treaties by Vietnam, questioning whether the Ordinance on the Conclusion and Implementation of International Agreements 1998 reflects an incorporation or transformation approach with respect to treaty adoption. Further evidence, specifically an analysis of the measures undertaken by Vietnam in fulfilment of its treaty obligations, the perceived application and effect of international treaties in Vietnam's socialist law regime and the treatment of treaties in domestic laws, will be relied on to conclude how treaties are adopted in Vietnam.

\section{CONCLUSION AND ADOPTION OF INTERNATIONAL TREATIES BY THE SOCIALIST REPUBLIC OF VIETNAM}

Under Article 102 of the Constitution of the Socialist Republic of Vietnam (hereafter 'Constitution'), the president is elected and capable of being removed by the National Assembly. The president is the head of state responsible for acting on behalf of Vietnam in domestic and foreign affairs, ${ }^{2}$ and has the duty and power under Article 103(10) of the Constitution 
to negotiate and sign international agreements on behalf of the Socialist Republic of Vietnam with the heads of other states; to approve or join international agreements, except in cases where a decision by the National Assembly is necessary.

The National Assembly has the obligation and power, under Article 84(13) of the Constitution

to decide fundamental policies in external relations; to ratify or annul international agreements that have been signed or participated in on the proposal of the country's President.

It is the role of the Standing Committee of the National Assembly 'to carry out the National Assembly's external relations'. ${ }^{3}$ The government-the executive arm of the National Assembly-has the duty and power under Article 112(8) of the Constitution, to conclude international treaties made in the name of the government, to undertake unified management of the external affairs of the state, and to direct the implementation of international treaties to which Vietnam has signed or acceded.

Pursuant to Articles 103 and $106^{4}$ of the Constitution, the president promulgated the Ordinance on the Conclusion and Implementation of International Agreements 1998 (hereafter 'Ordinance'), which governs the conclusion and adoption of international treaties in Vietnam. The ordinance replaced a similar ordinance enacted in 1989 (hereafter '1989 Ordinance').

The 1989 Ordinance had many problems and deficiencies. In particular, it was passed under the 1980 Constitution, which was replaced in 1992 by a constitution that established new structures and bodies within government with which the 1989 Ordinance was inconsistent (Doan Nang 1998). For example, the former Council of Ministers was replaced by the government, the powers of the State Council were transferred to the president and the National Assembly Standing Committee was divested of its explicit power with regard to the conclusion and adoption of treaties.

There were also difficulties with the signing, approval, ratification, reservation, suspension and cancellation of treaties. In particular, the provisions in the 1989 Ordinance were not sufficiently specific and did not clearly identify the role to be played by the Supreme People's Court and the Procuracy and other government agencies in negotiating and entering into treaties (Doan Nang 1998). The 1989 Ordinance also failed to distinguish between international agreements signed by the state and those signed by other ministerial authorities. The competence of the state and other ministerial authorities to enter into treaties, and many key terms, also had to be defined. A clear explanation was needed of the effect of entering into an international agreement on domestic law and the effect of withdrawing reservations (Doan Nang 1998; Vu Thu Hanh and Jin 1997). To remedy these defects, the government passed the new Ordinance.

The Ordinance maintains many similarities with its predecessor, but rectifies provisions made inaccurate by the passage of the Constitution and seeks to clarify those provisions that were previously unclear. This is important for our discussion because the Ordinance will apply only to those treaties ratified after the enactment. ${ }^{5}$ The 1989 Ordinance will continue to prescribe the rules for conclusion, adoption 
and implementation of treaties ratified between 1989 and 1998, but the new Ordinance can be used to illuminate ambiguities in the 1989 Ordinance.

\section{THE 1998 ORDINANCE ON THE CONCLUSION AND IMPLEMENTATION OF INTERNATIONAL AGREEMENTS}

Although similar to the 1989 Ordinance, the Ordinance is more expansive and overcomes some of the inadequacies of its predecessor. Notably, it sets out more clearly the rules to be applied by Vietnam in treaty negotiation, signature and ratification and the effect of treaties on domestic law. The purpose of the Ordinance is to specify the rules with regard to treaty practice in Vietnam and provide detail for the exercise of constitutional powers. The Ordinance consists of six chapters, which are further subdivided into 35 articles. The Ordinance is summarised below and in Figure 13.1.

\section{General provisions (Articles 1-4)}

Chapter 1 sets out the scope of application of the Ordinance. Article 1 details the stages of treaty conclusion, adoption and implementation that are regulated by the Ordinance and identifies the institutions that may conclude a treaty on behalf of Vietnam, namely

- the state

- the government

- the Supreme People's Court and the Supreme People's Procuracy

- the ministries and ministerial agencies.

Article 2 defines an 'international agreement' as all written arrangements concluded between Vietnam and one or many other nations, international organisations or other subjects of international law. For the purpose of this chapter, 'treaty' is used interchangeably with 'international agreement'. It also defines a number of terms used in treaty-making practice, including 'proxy', 'conclusion', 'approval', 'ratification', 'accession', 'reservation' and 'suspension', a feature absent from the 1989 Ordinance.

Article 3 sets out the principles to be applied in the conclusion of treaties, including the principle that international agreements must accord with the Constitution. ${ }^{6}$ Article 4 classifies international agreements according to the institutions with the power to negotiate and conclude particular types of treaties. ${ }^{7}$ The classification will depend on the character of the document and content of the treaty being entered into. Article 4(2) provides that the state may conclude treaties concerned with

- peace, security, borders, territory and national sovereignty (Article 4(2)(a))

- the rights and obligations of citizens (Article 4(2)(b))

- universal international and important regional organisations (Article4(2)(c))

- other contents agreed upon by the signatories (Article 4(2)(d)). 
Virtually all multilateral treaties fall within this category of international agreement. Most multilateral treaties lead to the loss of sovereignty of a state, as the obligations require the state either to act in a certain way or to prohibit acts. In cases where treaties do not affect the sovereignty of a nation, negotiating parties will nevertheless ordinarily demand that a treaty be concluded by the state, in its capacity as representative of all its citizens. Because the great majority of multilateral treaties fall within this classification, the discussion in this chapter focuses on this category of treaty.

Article 4(3) identifies those treaties that may be concluded by the government, including treaties made in the name of the state that are not prescribed under Article 4(2), and treaties concerning international and regional organisations beyond the scope of Article 4(2)(c).

Article 4(4) provides that the Supreme People's Court and the Supreme People's Procuracy may conclude treaties regarding international cooperation in areas within their jurisdiction.

Article 4(5) provides that the ministries and branches of the ministries may conclude treaties in the name of the state or government if the contents of the treaty fall within that ministry's or branch's field of competence and are not prescribed in Articles 4(2) and 4(3).

\section{Conclusion of international agreements (Articles 5-22)}

Article 5 sets out how treaties are to be entered into on behalf of the Vietnamese government, including their negotiation and signature. Articles 5(1) and 5(2) provide that the Ministry of Foreign Affairs, or another relevant ministry in consultation with the Ministry of Foreign Affairs, must submit all plans for the negotiation and signing of international agreements to the government.

Article 5(3) deals with preparation and negotiation of treaties. Where the treaty provisions are contrary to, or not yet stated in, any Vietnamese National Assembly or National Assembly Standing Committee legal documents, ${ }^{8}$ they must be submitted to the National Assembly for consideration. The proposing agency is obliged to consult with the relevant ministerial bodies and seek an evaluation from the Ministry of Justice. The government then considers the ministries' opinions before reporting to the National Assembly Standing Committee, which then submits its comments to the National Assembly.

Nations with a system of treaty incorporation typically require parliamentary approval of treaties containing provisions contradictory to, or not yet stated in, existing law. Although the National Assembly is not competent to decide whether or not to commence negotiations and sign an international treaty, ${ }^{9}$ the process of evaluation and consideration by the government and the National Assembly represents the first step in Vietnam towards such a parliamentary approval process.

The Ordinance provides for the National Assembly to receive extensive information to aid its consideration of the treaty. Article 5(4) provides that the report proposing the negotiation and signing of an international agreement must include 
- the aims of the agreement, particularly its effects on Vietnam's rights and obligations

- an evaluation of the political, economic and social financial impact

- an evaluation of the observance of Article 3 of the ordinance and other provisions of law

- opinions of the Ministry of Foreign Affairs and other relevant ministries

- the title of the treaty, the name in which it is signed, and the timeframe for its implementation

- issues requiring comment.

Article 6 details which institutions are competent to decide whether Vietnam will negotiate and sign treaties after the proposals for negotiation and signature have been considered in accordance with Article 5. They are

- the president, who will do so in the name of the state

- the government, in the name of the government

- the National Assembly Standing Committee, in consultation with the government, which decides the negotiation and signing of international agreements by the Supreme People's Court and the Supreme People's Procuracy

- heads of ministries, with the permission of the prime minister, in the name of their respective ministries.

Article 7 presents the rules regarding the persons or bodies that can negotiate and sign international agreements without a proxy, stating that the president, the prime minister, the Minister for Foreign Affairs, the President of Supreme People's Court, the Chair of the Supreme People's Procuracy and heads of diplomatic missions do not require a proxy.

Article 8, to new addition in the Ordinance, deals with the authorisation for the negotiation and signature of international agreements. Under this article, delegates are permitted to negotiate and sign a treaty on behalf of the state, the government, the Supreme People's Court or Procuracy, ministries or branches, provided these bodies have authorised the delegates to do so.

The process for ratification and approval of treaties is set out in Articles 9-11. ${ }^{10}$ Article 9 states that the agency proposing conclusion of a treaty must report to the government within 15 days of signing, providing a summary of the treaty's contents and a proposal for ratification or approval. ${ }^{11}$

Article 9(2) provides that the documents proposing ratification must include

- an evaluation of the agreement's impacts on Vietnam

- the necessary proposals on ratification or approval

- the opinions of the ministries concerned

- the contents of any reservation.

Article 10 states that treaties requiring ratification are those

- set out in Articles 4(2)(a) and 4(2)(b)

- that contain provisions contrary to, or are not yet provided for in, Vietnamese law 
- that relate to state business

- containing provisions on ratification.

Article 10(2) goes on to provide that the president will decide whether to ratify a treaty except where there is a need for the treaty to be submitted to the National Assembly, for instance where the laws of Vietnam are either contrary to, or are silent on, the provisions of the treaty. As in Article 5(3), parliamentary approval of the treaty is required in such circumstances before it may be ratified.

Although Article 10(2) of the Ordinance purports to grant the president the power to ratify international agreements, it is unclear whether the president has this power under the Constitution. Article 84(13) of the Constitution gives the National Assembly the power to 'ratify' international agreements, though the language used regarding the president in the Constitution is different. Under Article 103(10) of the Constitution, the president has the power to 'approve or join' international agreements. The government also has the power to 'join' and 'approve' international agreements (on behalf of the government). As has already been noted, the Ordinance distinguishes between the processes of 'ratification' and 'approval'. If one were to apply the definitions in the Ordinance to the Constitution, the president would be prevented from ratifying international agreements.

Article 10(2) of the Ordinance is also inconsistent with the more authoritative Law on the Promulgation of Legal Documents (hereafter 'the Law' $).{ }^{12}$ Under Article 20(2) of the Law, the National Assembly holds the power to issue resolutions ratifying international agreements. The Law contains no similar provision giving the president the power to issue resolutions ratifying treaties. Instead, the president's power is limited to promulgating (proclaiming) the resolutions of the National Assembly, pursuant to Article 50 of the Law.

The process of ratification is set out in Article 10(3) of the Ordinance. The ministry or agency that proposed the conclusion of the treaty coordinates with the Ministry of Foreign Affairs to submit to the president a proposal for ratification. The president has 30 days to give an opinion on the submission. Once the decision to ratify has been made, the Ministry of Foreign Affairs has 15 days to put in place the diplomatic procedure required to finalise the treaty, including notifying the relevant agencies of the treaty's effects.

The process for the approval of international agreements is set out in Article $11 .{ }^{13}$ This article provides that international agreements signed in the name of the government or a ministry and that contain provisions on approval or provisions contrary to or not yet regulated by the legal documents of the government require the approval of the government. Articles 11(3) and 11(4) detail the process of approval, which is similar to the ratification process outlined above.

Article 12 deals with accession to multilateral international agreements, describing who may seek accession of a treaty and the process involved in seeking approval or ratification according to terms of the treaty, including the documentation required and the time within which a decision is to be made. ${ }^{14}$ 
Article 13 provides that bilateral agreements must be in Vietnamese and that treaties signed in foreign languages must be translated into Vietnamese.

Article 14 provides that an international agreement concluded in the name of the state or government must be sealed by the Ministry of Foreign Affairs.

Articles 15 and 16 set out the procedures and rules with regard to reservations to international agreements.

Article 17 deals with the effect of international agreements and states that an international agreement will come into force in Vietnam according to the provisions of the agreement or under other arrangements made between the signing parties. The article also states that treaties may come into force temporarily in circumstances where full conclusion of a treaty is conditional on the occurrence of a later event under the control of the state. ${ }^{15}$

\section{Promulgation and depository of international agreements (Articles 18-22)}

Article 18 states that the Ministry of Foreign Affairs will manage and archive the original texts and instruments of ratification of international agreements, and Article 19 provides that the Ministry for Foreign Affairs must send duplicates of international agreements to the National Assembly, the president, the government and others.

Article 20 deals with the details of the promulgation of international agreements. It provides that all agreements must be promulgated, that is, proclaimed as a law of Vietnam, unless otherwise decided by the signing parties, the president or the government. The state must perform the promulgation of international agreements, in accordance with Article 30 of the Ordinance (see below), which is a function normally performed by the president. ${ }^{16}$ An international agreement promulgated under Article 20 must be published in the Official Government Gazette within 15 days of the agreement taking effect. ${ }^{17}$

Under Articles 21 and 22, the Ministry of Foreign Affairs is required to register international agreements with the relevant international organisation and perform the function of depositary of international agreements where Vietnam is the depositary nation.

\section{Implementation of international agreements (Articles 23-29)}

Article 23 provides that Vietnam must strictly observe international agreements it has concluded. Article 24-'Ensuring the implementation of international agreements' - sets out the actions that must be undertaken for the implementation of international agreements. It provides that

- the agencies that propose the conclusion of international agreements submit to the government plans on the implementation of those agreements, clearly stating the implementation schedule, organisational, managerial and financial measures and other suggestions to ensure the implementation of the agreement. 
- the concerned ministries and/or branches shall, within their functions, tasks and powers, implement the international agreements already concluded by Vietnam.

- in cases where an international agreement is breached, the agency that has proposed the conclusion of such agreement or the concerned state agency will coordinate with the Ministry for Foreign Affairs in proposing to the government measures necessary to protect the legitimate rights and interests of Vietnam.

- annually, and when requested, agencies that propose the conclusion of international agreements and relevant state agencies shall submit to the government and the president reports on the implementation of the concluded international agreements. Such reports must also be submitted to the Ministry for Foreign Affairs for monitoring.

- in cases where the implementation of an international agreement requires that legal documents of Vietnam be amended, supplemented, annulled or replaced, the agency that proposed the conclusion of the agreement and the relevant state agencies will promptly organise those changes, either directly or through another relevant state agency, in accordance with the Law on the Promulgation of Legal Documents.

Article 25 identifies the people and agencies with the authority to seek the amendment, supplement or extension of international agreements. Namely, state agencies entitled to negotiate a treaty under Article 6 are entitled to make amendments, and the institution that ratified the treaty also has the power to make amendments (Article 25(1)). These bodies must, however, first consult with, and obtain comments from, the Ministry of Foreign Affairs (Article 25(2)). Article 25(3) requires the documents that propose an amendment include

- the aim of the amendment

- the legal basis of the amendment

- the written comments from the Ministry of Foreign Affairs and others

- the contents of the amendment together with the international agreement.

Once an amendment has been decided on, the institution then coordinates with the Ministry of Foreign Affairs in completing the procedures for that amendment (Article 24(4)).

The grounds for suspension and termination of international agreements are set out in Article 26. A treaty may be suspended or terminated

- according to its own provisions

- where there is a violation of the conclusion principles prescribed in Article 3 of the ordinance

- where the international agreement is seriously violated by the other signatories.

The institution that ratified, approved or acceded to the international agreement has the competence to decide the suspension and termination of the agreement 

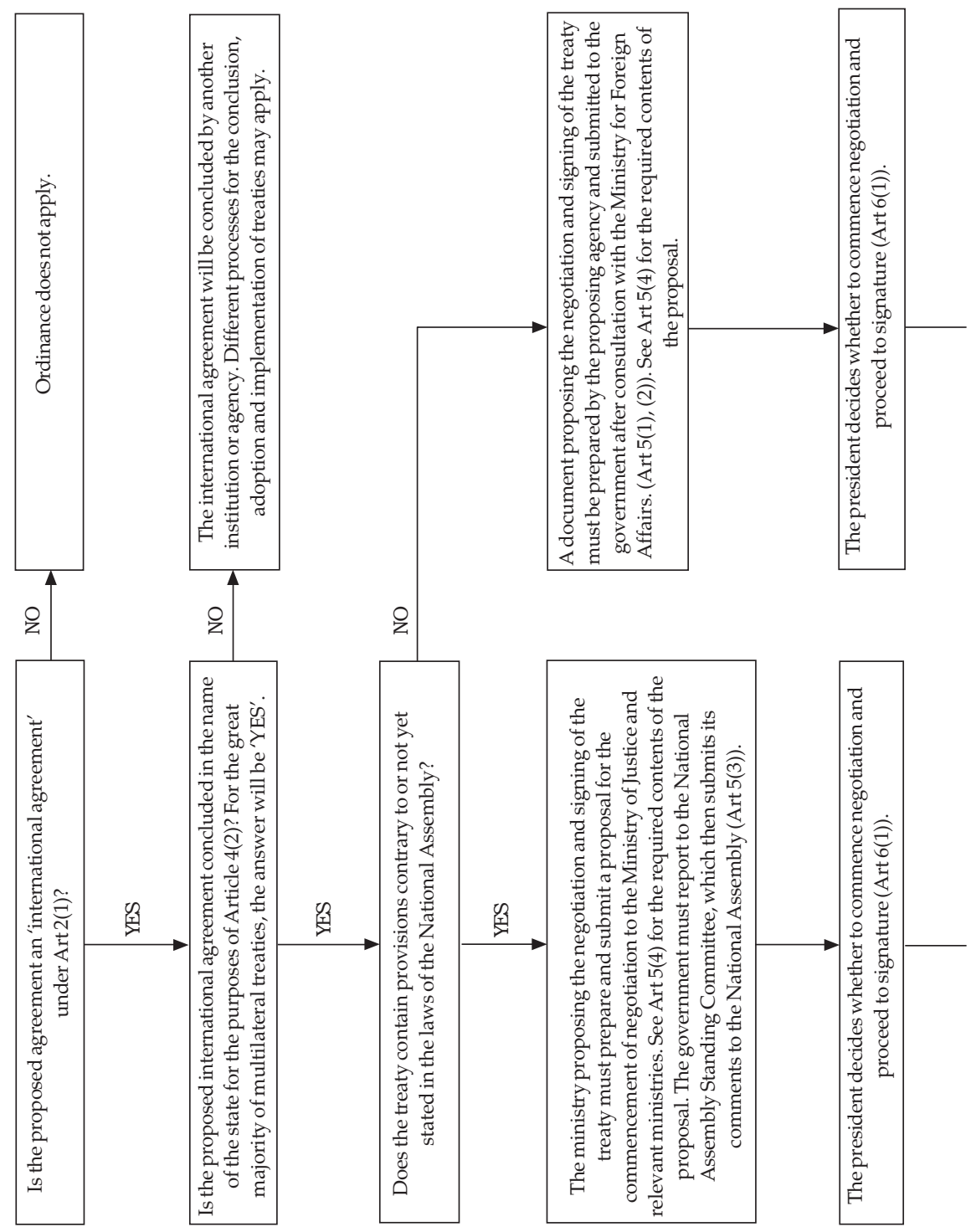

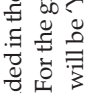

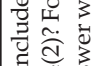

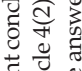

范

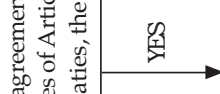

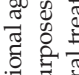

吾

节泀

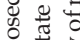

苋苦

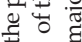

.

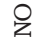

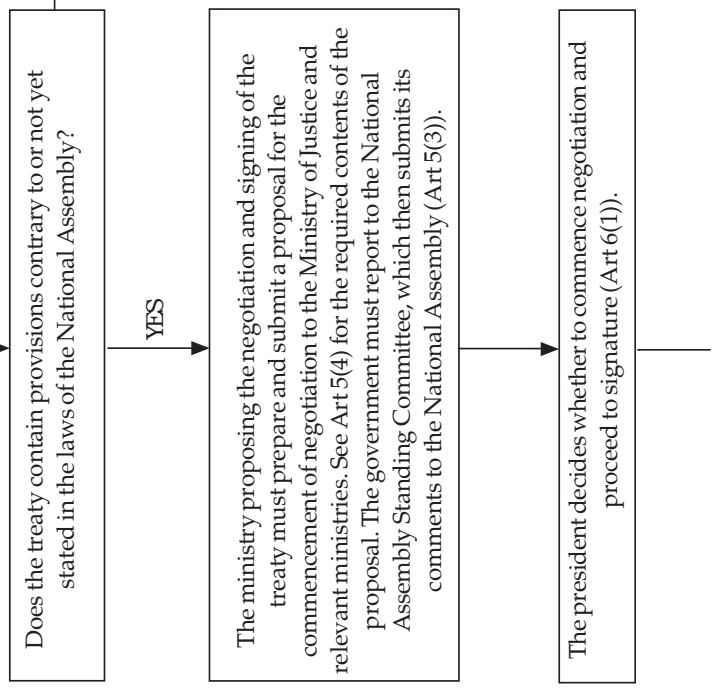



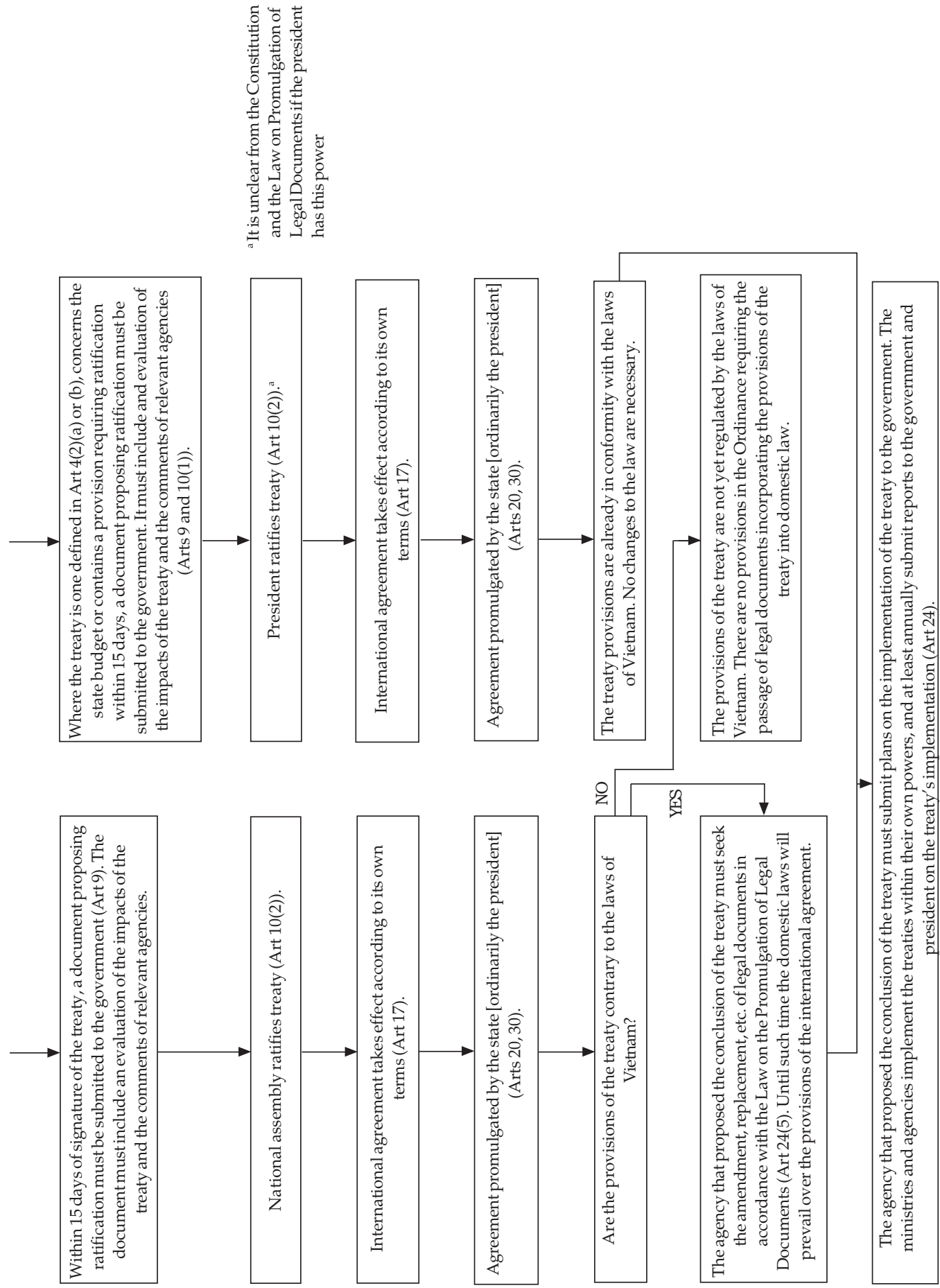

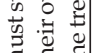

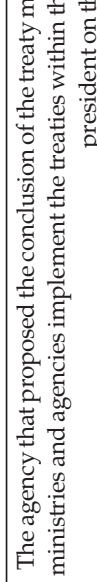


(Article 27), but a report must be provided to underpin any proposal for such an action (Article 28).

The rules regarding the interpretation of international agreements are detailed in Article 29. Generally, the contents of international agreements must be interpreted in accordance with international law. Where conflicting interpretations arise, the government must resolve the conflict.

The National Assembly Standing Committee is competent to interpret international agreements ratified by the National Assembly and international agreements that contain provisions contrary to, or not yet provided for in, legal documents promulgated by the National Assembly or the National Assembly Standing Committee. The institution in whose name the treaty was concluded is also competent to interpret the international agreement.

\section{State management over the conclusion and implementation of international agreements (Articles 30-33)}

Article 30 details the state's role in the domestic process of concluding, adopting and implementing international agreements, specifically that the state is responsible for

- promulgating legal documents on the conclusion and implementation of international agreements

- organising and ensuring the implementation of international agreements

- popularising, disseminating and guiding the implementation of legislation on the conclusion and implementation of international agreements.

- collecting state statistics on international agreements

- organising the archiving and deposit of international agreements

- supervising, inspecting, examining and handling violations of the legislation on the conclusion and implementation of international agreements

- settling complaints and denunciations related to the conclusion and implementation of international agreements.

The functions required of the state in Article 30 must be exercised by the government, assisted by the Ministry for Foreign Affairs and other ministries and agencies, according to Article 31.

Pursuant to Article 32, the National Assembly, National Assembly Standing Committee and the government must supervise the conclusion, adoption and implementation of international agreements.

\section{Implementation provisions (Articles 34-35)}

Article 34 provides that the government must issue separate regulations on the conclusion, adoption and implementation of international compacts concluded by provinces and cities that are directly under the control of the government and by other organisations. 
The agency that proposed the conclusion of the treaty must submit plans on the implementation of the treaty to the government. The ministries and agencies shall implement the treaties within their own powers, and at least annually submit reports to the government and president on the implementation of the treaty (Article 24).

\section{EVALUATION OF THE PROCESS OF IMPLEMENTING TREATIES INTO DOMESTIC LAW}

Although the Ordinance provides detailed rules on the procedures concerning the conclusion, adoption and implementation of treaties in Vietnam, it does not clearly specify whether a treaty that has been ratified is self-executing or requires the enactment of legislation to incorporate the treaty obligations into Vietnamese domestic law. The question of whether the treaty-making process reflects an incorporation or transformation approach is an important one. Because Vietnam has rarely enacted laws to 'transform' the provisions of international treaties into municipal law, if the Ordinance and practice in Vietnam reflects a transformation approach, then the legal regimes established in international treaties will not displace domestic laws in Vietnam, they will not be enforceable and Vietnam would not be complying with its international obligations.

The articles in the Ordinance that provide the rules regarding the adoption of treaties are examined, to analyse the perceived application and effect of international treaties in Vietnam's socialist law regime, and to investigate state practice with respect to treaty adoption and implementation to determine whether an incorporation or transformation approach to treaty adoption prevails in Vietnam.

\section{The competing doctrines of incorporation and transformation}

The relationship between international law and domestic laws may be described by the competing theories of monism and dualism. The theory of monism posits that international law and domestic law are part of the same legal system, which may be enforced in the domestic or international arena, and international law will prevail where there is conflict. Conversely, the theory of dualism posits that international law and domestic law operate in different spheres and regulate different legal systems (Fitzmaurice 1957). Under the dualist theory, domestic laws regulate the internal activities of a state and its constituents and international law regulates the relations between states. International law must be transferred into the domestic law before creating individual rights (Balkin 1997).

With respect to the status of international treaties in domestic law, the doctrines of incorporation and transformation reflect the application of monist and dualist theories respectively.

The doctrine of incorporation, which reflects the monist theory, posits that a rule of international law becomes part of the municipal law without being expressly adopted by the legislature or the courts of the state (Shaw 1997)—its ratification 
results in its incorporation into a domestic legal system. The international law is said to be self-executing. With respect to treaties, a treaty ratified by the state will be incorporated into municipal law immediately on coming into effect.

By contrast, the doctrine of transformation, which reflects the dualist theory, posits that the rules of international law do not become part of municipal law until they have been expressly and deliberately enacted into domestic law by the use of the appropriate constitutional machinery, for instance, by the passage of a law through the state's legislature (Shaw 1997). Without transformation, the rights and obligations within international treaties may not be enforced in the domestic sphere; they operate only within international dispute mechanisms (Balkin 1997).

Much of the world, with the exception of a number of current and former territories of the British Empire and a collection of other nations, takes the incorporation approach to treaty-making. This is largely a result of the fundamental doctrine of pacta sund servanda. The principle was given the force of a treaty in the Vienna Convention on the Law of Treaties in 1969, Article 26 of which provides that 'each existing international treaty shall be binding upon all State Parties and implemented voluntarily by them' (Vu Duc Long, forthcoming).

For example, in Germany, Article 25 of the Basic Law of the Federal Republic of Germany provides that the rules of international law are incorporated into German domestic law and take precedence over domestic legislation. Similarly, Articles 93 and 94 of the Netherlands' 1983 Constitution provide an incorporation approach to treaty-making. In South Africa, ratification of a treaty is a function of the parliament (Section 231(2) of the South African constitution) and upon ratification the treaty provisions become part of the law of the republic (Shaw 1997).

In France, treaties ratified and officially published operate as laws in the domestic sphere. Article 55 of the French constitution provides that 'from their publication, duly ratified or approved treaties or agreements have a higher authority than [domestic laws] subject for each treaty or agreement, to its implementation by the other party'. A number of classes of treaties may, however, only be ratified through the enactment of legislation (Shaw 1997). ${ }^{18}$

Similary, Article 15(4) of the Russian constitution adopts a rule of incorporation of treaties (Shaw 1997), stating that, where there is an inconsistency between a domestic law and a treaty obligation, the treaty will prevail. This position is reiterated in Article 5 of the Federal Law of the Russian Federation in International Treaties of the Russian Federation. Article 5(1) provides that concluded treaties are an 'integral part' of the Russian legal system and Article 5(3) provides that provisions of international treaties adopted by Russia 'shall operate in the Russian Federation directly' (Butler 2002).

Although China has no constitutional provisions or specific laws dealing with the conclusion and implementation of treaties, Li Zhaojie (1993:62) concludes, based on provisions in certain laws and Chinese state practice, that China incorporates ratified treaties directly into its domestic laws. Article 142 of China's General Principles of Civil Law, for instance, states that 
[i]f any international treaty concluded or acceded to by the People's Republic of China contains provisions different from those found in the civil laws of the People's Republic of China, the provisions of the international treaty shall prevail, except for the provisions to which the People's Republic of China has declared its reservations (Li Zhaojie 1993:79).

China's domestic laws relating to taxation, foreign investment, pollution, the environment and diplomatic privileges and immunities all contain provisions stating that a treaty will prevail over an inconsistent domestic law.

The Japanese process of concluding and adopting international treaties, which has been considered as reflecting an incorporation approach, is similar to that in Vietnam. In Japan, a treaty becomes a part of domestic law after the Diet has approved and the Cabinet ratified it. ${ }^{19}$ Article 98(2) of Japan's constitution provides that treaties concluded by Japan 'shall be faithfully observed'. Shaw (1997) argues that this provision, which requires a step of parliamentary approval, reflects an incorporation approach. Interestingly, it is similar to Article 23 of Vietnam's Ordinance, which requires Vietnam to 'strictly observe' international agreements it has concluded.

The various approaches adopted in France-Vietnam's former colonial rulerneighbouring countries such as China and Japan, and Russia-a former socialist nation-are instructive when determining Vietnam's approach to the conclusion of treaties. Some of these nations' laws do share similarities with Vietnamese laws, and each incorporates treaties into domestic law. These nations are a part of the large majority of nations who either expressly or by state practice, based on the Vienna Convention on the Law of Treaties, incorporate treaties directly into their domestic laws.

A minority of nations, led by the United Kingdom, and most nations of the Commonwealth, adopt a transformation approach to treaty provisions (Brownlie 1990). ${ }^{20}$ In Attorney General for Canada v Attorney General for Ontario, ${ }^{21}$ Lord Atken stated that

within the British Empire there is a well-established rule that the making of treaties is an executive act, while the performance of its obligations, if they entail alteration of the existing domestic law, requires legislative action...the stipulations of a treaty duly ratified do not within the Empire, by virtue of the treaty alone, have the force of law.

The rationale behind the adoption of the transformation approach in countries such as the United Kingdom, Australia and Canada, is that under their constitutions the executive is responsible for negotiating, signing and ratifying treaties. The institution with the power to make and amend laws, the legislature, is not involved in the treaty-making process. If treaties were automatically to become part of the law of these nations, the consequence would be that the executive could alter the laws of the state without consulting parliament (Shearer 1994; Jacobs 1987).

The same principle can be seen to operate in most of the nations where an incorporation approach to treaty provisions prevails. In nations such as France, Germany, South Africa and Japan, parliamentary approval of treaties occurs prior to, or is part of, the process of treaty ratification. In a sense, then, it could be argued that whether a nation adopts an incorporation or transformation approach to treaties will depend largely on when, if at all, parliament is involved in approving treaties. 
Where the nation's parliament is involved in approving the text and obligations of the treaty before it comes into force, that nation will probably adopt an incorporation approach. Conversely, where the parliament is not involved in the treaty-making process, it will generally have a role in reviewing the treaty and deciding whether to give effect to its obligations after the treaty is in force. In such a nation the transformation approach is likely to be followed (Jacobs 1987).

\section{The approach adopted in Vietnam}

Vietnam's socialist legal regime. According to Marxist interpretations of democratic legal systems, the law is a reflection or an instrument of capitalism, used by capitalist states to maintain a privilege over other states in the international sphere and over the working classes in the domestic sphere. ${ }^{22}$ The suspicion with which Vietnam treats democratic legal systems is expressed in its own legal system-described as being aimed at developing Vietnam in accordance with the socialist orientation, as opposed to the laws of the 'bourgeois state', which are aimed at protecting capitalism (AusAID 2001). While Vietnam's National Assembly is active, most legal controls are enacted and enforced by the administration through orders and decrees, bypassing the scrutiny of the democratic parliament (Gillespie 1997).

Since the doi moi reforms began in 1986, Vietnam has begun to participate in the international legal community and to ratify and accede to international treaties, principally motivated by the need to attract foreign investment to Vietnam and to integrate the Vietnamese economy into regional and international economies (AusAID 2001; Doan Nang 2002). But Vietnam has maintained its suspicion of international law, and Vietnamese bureaucrats believe that international treaties do not apply in the socialist domestic legal system - in accordance with the theory of dualism, they argue that the international and domestic legal spheres are not integrated. Doan Nang, the head of the legal group within the Ministry of Science, Technology and Environment, for instance, states that the socialist legal system dictates that national sovereignty and self-determination must be respected when entering and implementing international treaties. The mere conclusion of an international treaty does not elevate the obligations and rights in the treaty above those found in the domestic law (Doan Nang 2002). Although Doan Nang rejects the doctrine of transformation on the basis that it is impossible for states to transform international laws into domestic laws, his comments that Vietnam must and will enact laws when required in an international treaty (and that the international treaty does not automatically become the law of the state) in fact indicate that the doctrine of transformation is his understanding of Vietnam's approach to adopting international treaties (Doan Nang 2002:39). That is, that rights and obligations imposed on individuals will not become operative unless and until the rights and obligations are expressed in domestic laws.

China, which shares Vietnam's socialist ideals, appears less opposed to the incorporation of international treaties into its domestic laws. Domestic laws relating to taxation, foreign investment, pollution, the environment and diplomatic privileges and immunities all contain provisions stating that a treaty will prevail over an 
inconsistent domestic law, a reflection of the application of the monist international law theory and the doctrine of incorporation in China (Li Zhaojie 1993). The Chinese approach demonstrates that a socialist legal regime is capable of recognising the incorporation of international treaties, at least within specified jurisdictions. Therefore, the mere fact that Vietnam's legal system is a socialist one does not mean that an incorporation approach cannot prevail in Vietnam. Rather, the approach adopted should be determined through an analysis of Vietnam's laws, particularly the Ordinance, and state practice.

The Ordinance. It has been noted that the Ordinance does not explicitly adopt either an incorporation or transformation approach to the conclusion of treaties. The Ordinance does contain a number of articles similar to those in other 'incorporation' nations, but also has a number of articles that appear more consistent with a transformation approach.

The Ordinance (as shown in Figure 13.1) creates a different process for treaties where

1. the provisions are already prescribed in domestic law

2. the treaty provisions are not yet stated in the laws of Vietnam

3. the treaty provisions are contrary to the laws of Vietnam.

In the first class of treaty, the issue of incorporation versus transformation is irrelevant as the treaty provisions are a part of the domestic law of Vietnam before the treaty is signed and ratified. In the second and third classes, the negotiation and signing of treaties to be concluded in the name of the state must be approved by the president following consideration by the National Assembly (Articles 5(3) and 6(1)). Treaties falling into these classes must also go through a process of ratification. Although the Ordinance purports to require treaties be ratified by the president (Article 10(2)), the Constitution and the Law on the Promulgation of Legal Documents appear to reserve this power for the National Assembly. Nevertheless, according to Article 10(2), only the National Assembly may ratify treaties containing provisions contrary to, or not yet stated in, the domestic laws of Vietnam. Consequently, when the treaty enters into force it will have twice been considered by the National Assembly and approved on one occasion. Only treaties containing provisions that comply with pre-existing domestic laws may be ratified by the president. It is therefore arguable that the treaty has already been 'ratified' by the National Assembly.

This process is common to those nations that adopt an incorporation approach. Given that the National Assembly, the highest parliamentary body in Vietnam, has approved these treaties, it can be strongly argued that the moment the treaties enter into force their provisions become the law of Vietnam. The Ordinance, however, may require additional action.

Where the treaty contains provisions contrary to the domestic laws of Vietnam (class 3 above), the implementation of the international agreement requires 'legal documents of the Socialist Republic of Vietnam to be amended, supplemented, annulled or replaced... promptly in accordance with the Law on the Promulgation of Legal Documents' (Article 24(5)). 
The Law sets out the types of legal documents that require promulgation and the institutions competent to promulgate them. It also specifies the rules and procedures for passing different types of legal rules into domestic law. Article 24(5) of the Ordinance means that, if an international obligation requires an amendment, supplement, annulment or replacement of a domestic law, then that change will have to go through the process required under the Law on the Promulgation of Legal Documents.

Because the Ordinance requires the alteration of domestic laws to comply with international obligations, where an international obligation entered into by Vietnam has an effect on an existing domestic law, the international obligation will prevail over the inconsistent domestic law but will first require the appropriate changes to be made to the existing domestic law. The inconsistent treaty obligation will not be self-executing but will require the passage of laws making the appropriate changes. The international obligation that conflicts with a domestic law will not take effect or form part of domestic law until the change has been made domestically. Article 24 is not clear on the process where an international agreement does not affect existing domestic law but does introduce a new obligation with domestic implications (that is, a 'class 2 ' treaty).

Under Article 24(1) the agency that proposed the conclusion of an international treaty is 'required to submit to the government plans on the implementation of international agreements including a schedule, organisational managerial and financial measures'. Article 24(4) requires state agencies that have concluded international agreements to submit reports on their implementation to the government and the president. These provisions, particularly given their silence on the need to enact legal documents, presuppose that the treaty provisions have already become law by the time the relevant agencies are developing plans and measures to give practical effect to the treaty's terms.

Indeed, interviews conducted with Mr Nguyen Ba Son Zang of Vietnam's Department of Foreign Affairs and Dr Dao Duc Tuan, Director of the National Office for Climate Change and Ozone Protection, have confirmed that, where treaties are not yet stated in or not inconsistent with the domestic laws of Vietnam, they will be self-executing. . $^{23}$

In summary, with regard to the issue of incorporation and transformation of concluded international agreements, the provisions of the ordinance, though not explicit, suggest that

- treaties that are contrary to the pre-existing laws of Vietnam will need to be 'transformed' into the domestic law of Vietnam. They will not be effective until the relevant laws are amended or repealed.

- treaties with provisions that are not yet stated in the laws of Vietnam will be automatically incorporated in the domestic law when the treaty comes into effect.

State practice. No specific domestic laws implementing international treaty obligations seem to have been passed. In Vietnam, treaty obligations tend to be 
implemented by the administration, using under-laws (typically circulars and resolutions), policies, strategies or action plans rather than specific laws passed by the National Assembly. These types of laws are more quickly and easily passed than those of the National Assembly, which meets just twice a year, and fit Vietnam's socialist legal system, in which legal control is generally exercised by administrators loyal to the government. Incorporation, because it is efficient and convenient, seems to be the approach adopted when treaty provisions are consistent with pre-existing domestic laws. If Vietnam adopted a transformation approach, whereby the rights and obligations imposed by international treaties remain in the international law sphere until given effect by the enactment of domestic laws, those obligations and rights, because of the nature of the Vietnamese socialist legal system, would be unlikely ever to be applied.

Environmental law provides some examples of situations where Vietnam has used policies and under-laws to implement international obligations without first passing legislation to transform international treaties. ${ }^{24}$

- Vietnam ratified the Convention on Biological Diversity in 1994. There is no comprehensive legislation implementing the convention's obligations, but a Biodiversity Action Plan 1995 is in place.

- Vietnam acceded to the World Heritage Convention in 1987, and between 1994 and 2003 two natural and three cultural heritage sites have been inscribed on the World Heritage List. There are, however, no laws in place protecting these sites from human interference.

- Vietnam ratified the Law of the Sea Convention in 1994. Various documents have identified the need for marine and coastal conservation programs and territorial sea delimitation.

- Vietnam acceded to the Convention on International Trade of Endangered Species in 1994. Article 29(5) of the Law on Environment Protection prohibits trading in precious or rare species of plants and animals, and the Council of Ministers passed the 1992 Decree Determining the List of Precious and Rare Wild Plants and Animals and Regulating Their Management and Protection.

- Vietnam acceded to the Convention on Wetlands of International Importance (Ramsar) in 1989. To date, one site has been listed as a Ramsar site- the Xuan Thuy Natural Wetland Reserve in the Red River Delta, and the Biodiversity Action Plan proposes the establishment of 64 protected wetland areas.

- Vietnam acceded to the Vienna Convention on Ozone Depletion and the Montreal Protocol in 1994, and the Vietnam Country Programme for the Phase out of Ozone Depleting Substances was formulated in 1994.

There are also domestic laws that specifically refer to international treaties and their effects. Direct reference to international agreements and their obligations is made in the Civil Code (Article 827), the Commercial Code (Article 4(1)), the Maritime Code (Article 23) and the Law on Environment Protection (Articles 24 and 25). 
Article 827(2) of the Civil Code provides that, where it is in conflict with an international agreement, the international agreement prevails. Similarly, Article 4(1) of the Commercial Code states that, where a provision of the code is inconsistent with an international treaty obligation, the international obligation prevails. Article 23(1) of the Maritime Code makes reference to ships operating within Vietnamese territorial waters, stating that ships both of Vietnam and of foreign countries must observe 'the provisions of any international agreements to which Vietnam has signed or recognised'.

All three examples here seem to indicate adoption of the incorporation theory. They assume that obligations under international agreements entered by Vietnam are a part of the domestic law, but do not identify how this should be achieved.

Chapter V of the Law on the Protection of the Environment deals with 'International Relations in Respect of Protection of the Environment'. Article 45 provides that Vietnam shall implement 'all international treaties relating to the environment to which it is a signatory or participant, and shall respect all international treaties relating to protection of the environment on the basis of respect for independent sovereignty, territorial claim and mutual benefit'.

Article 48 provides that

Where a dispute relating to protection of the environment arises in the territory of Vietnam and involves one or more foreign parties, the dispute shall be resolved by the governing laws of Vietnam and also by reference to international laws and practices. Any dispute between Vietnam and other countries in respect of the environment shall be resolved by way of negotiation, taking into account international laws and practices.

The Law on the Protection of the Environment does not detail how international treaties are to be implemented into domestic law (whether automatically upon entry into force or through the enactment of legislation), but these articles firmly state that Vietnam is obliged to fulfil the terms of any environmental treaty and supports the conclusion that obligations within treaties not inconsistent with pre-existing laws are automatically incorporated into the domestic law of Vietnam.

Although an analysis of state practice supports the assertion that treaties containing provisions not inconsistent with pre-existing domestic laws will automatically be incorporated into the domestic laws of Vietnam, it is not emphatic.

\section{CONCLUSION}

Although Vietnam has an Ordinance on the Conclusion and Implementation of International Treaties it does not clearly identify whether obligations under treaties ratified are self-executing or not. The only conclusion that is consistent with the articles of the Ordinance and current state practice, however, is that treaties that are not inconsistent with the domestic laws of Vietnam are self-executing. This view is shared by Dr Vu Duc Long (forthcoming) who concludes that ratified and concluded treaties are incorporated into Vietnam's domestic laws upon entry into force. Those 
treaties with obligations contrary to the pre-existing laws of Vietnam, however, will not become the law of Vietnam until the inconsistent legal document has been amended or replaced. Thereafter, the obligations under international agreements will prevail over any later domestic law.

This conclusion is not supported by other Vietnamese bureaucrats, including Doan Nang, who claims that socialist legal theory dictates that international laws are not integrated into the domestic legal system (Doan Nang 2002). Widespread acceptance of Doan Nang's claims, which are not reflected in the Ordinance, would result in a stifling of legal development in Vietnam. It would mean that the many international treaties that Vietnam has ratified or acceded to would only be binding on the state in the international legal system and would not operate to advance the livelihood of Vietnamese citizens or the protection of the environment.

It would be beneficial if Vietnam amended the Ordinance to include a provision that sets out clearly whether obligations under international agreements are incorporated into the domestic law of Vietnam upon their entry into force or whether further action is required by the state before the obligations are transformed into domestic law. The National Assembly appears to have acknowledged that benefits would flow from clarifying the relationship between Vietnamese domestic laws and treaties concluded by Vietnam, which is largely absent from the Ordinance. On 23 May 2005, the National Assembly passed the Law on Signing, Joining and Implementing International Treaties. This new law will commence on 1 January 2006 and will replace the Ordinance. All treaties concluded from 2006 will be subject to this new regime. An English language draft of the new law, dated 5 April 2005 and distributed at the National Assembly Foreign Affairs Committee workshop 'International Treaties and Roles of Legislatures', indicates the drafters' intention to include an article in the new law addressing the relationship between domestic laws and treaty obligations.

The draft law proposed a new Article 4 'International treaties and provisions of domestic law'. The final expression within this article, however, remained contentious, with various drafting options included in the draft version of the law. Generally, the options all reflected an incorporation approach to treaty adoption, supporting the conclusion reached in this chapter about the current approach in Vietnam.

It would be helpful if the new law describes how international obligations to which Vietnam is a party are to be adopted (either through transformation or incorporation) and implemented. This would be especially important where an obligation in a treaty requires the taking of specific action, for example, the passing of domestic controls or laws. As Vietnam becomes increasingly deeply connected with the rest of the world, and particularly as multinational corporations seek to invest in the country, issues of which sphere of law they are bound by-domestic or international—will grow more pressing. 


\section{NOTES}

1 The authors have used the word 'adoption' to describe the process (either incorporation or transformation) of bringing international treaty obligations into a nation's domestic laws. 'Implementation' is used to refer to the process of introducing programs, policies or laws after treaty obligations have been adopted to give effect to and fulfil the obligations within the treaty.

2 Article 101, Constitution of the Socialist Republic of Vietnam.

3 Article 91(11) of the Constitution of the Socialist Republic of Vietnam. The Standing Committee of the National Assembly comprises the Chairman and Vice-Chairmen of the National Assembly and other members determined by the National Assembly. A member of the Standing Committee, however, may not also be a member of the government.

4 Article 106 provides that the president shall issue orders and decisions for the accomplishment of his duties and the exercise of his powers.

5 Article 76(1) of the Law on the Promulgation of Legal Documents states that 'only in extremely necessary cases a legal document may have a retroactive effect'.

6 A similar provision was contained in Chapter 2 of the 1989 Ordinance.

7 This is similar to Article 3 of the 1989 Ordinance.

8 That is, any laws, resolutions and ordinances. See Articles 1(1) and (2) of the Law dated 12/11/ 1996 of the National Assembly on the Promulgation of Legal Documents.

9 See Article 6 of the Ordinance and Article 84(13) of the Constitution.

10 The Ordinance distinguishes between acts of conclusion by the state and the government. Under Article 2, 'ratification' is a legal act undertaken by the National Assembly or President acknowledging the effect of the concluded treaty to Vietnam. 'Approval' is defined as a legal act by the government, acknowledging the effect of a concluded treaty to Vietnam.

11 A similar provision was contained in Article 7 of the 1989 Ordinance.

12 An 'ordinance' is a by-law enacted by the National Assembly Standing Committee. A 'law' is enacted by the National Assembly.

13 This was previously set out in similar terms in Article 8 of the 1989 Ordinance.

14 This was provided for in Article 9 of the 1989 Ordinance.

15 For example, the fulfilment of trade liberalisation requirements.

16 Authors' personal email communication with Ly Quoc Hung, Deputy Chief of Press, Publications and Public Information Division of the National Assembly of Vietnam, 16 July 2001 and 11 August 2001.

17 The government's Decree No. 161/1999/ND-CP, dated 18 October 1999, regulates the promulgation process in further detail.

18 Under Article 53 of the French Constitution, parliament must ratify peace treaties, commercial treaties, treaties relating to international organisations, treaties which commit the finances of the state, treaties relating to the status of persons, and those treaties involving the transfer, exchange or addition of territory.

19 Article 7 of the Japanese Constitution.

20 Some exceptions do exist. For example, treaties relating to the conduct of war or cession of territory. See Shaw (1997:112).

21 [1937] AC 326.

22 See, for example, Sampford (1989) and Keach (2003).

23 Personal communication [interview with Tannetye Bryant] with Nguyen Ba Son Zang, Department of Foreign Affairs in Vietnam, 6 November 2000. Also personal communication [interview with Tannetye Bryant] with Dao Duc Tuan, Director of the National Office for Climate Change and Ozone Protection of Vietnam, 7 November 2000.

24 See further Bryant and Jessup (2002).

\section{REFERENCES}

AusAID, 2001. Vietnam: Legal and Judicial Development, Working Paper 3, AusAID, Canberra.

Balkin, R., 1997. 'Chapter 5: International law and domestic law', in S. Blay, R. Piotrowicz and B.M. Tsamenyi, Public International Law: an Australian perspective, Oxford University Press, Melbourne:119-45. 
Brownlie, I., 1990. Principles of Public International Law, Clarendon Press, Oxford.

Bryant, T. and Jessup, B., 2002.'The status of international environmental treaties in Vietnam', Asia Pacific Law Review, 10(1):117.

Butler, W.E., 2002. The Law of Treaties in Russia and the Commonwealth of Independent States, Cambridge University Press, Cambridge.

Doan Nang, 1998. 'Perfecting the legislation on signing and implementing international agreements', Vietnam Law \& Legal Forum, May:18.

_ 2 2002. 'Right settlement of relationship between international and national laws', Legislative Studies Magazine, 5/ 6:39 (translated into English).

Fitzmaurice, G., 1957. 'The general principles of international law considered from the standpoint of the rule of law', in D.J. Harris, 1998. Cases and Materials on International Law, Fifth edition, Sweet \& Maxwell, London:68-70.

Gillespie, J., 1997. 'Bureaucratic control of business regulation in Vietnam', in V. Taylor (ed.), Asian Laws Through Australian Eyes, Law Book Company, North Ryde:367-400.

Harris, D., 1998. Cases and Materials on International Law, Fifth edition, Sweet \& Maxwell, London.

Jacobs, F., 1987. 'Introduction', in F. Jacobs and S. Roberts (eds), The Effect of Treaties in Domestic Law, Sweet \& Maxwell, London:xxiii-xxx.

Keach, B., 2003. 'International law: illusion and reality', International Socialist Review, 27:n.p. Available online at http:/ / www.isreview.org/issues/27/27.shtml.

Li Zhaojie, 1993. 'Effect of treaties in domestic law: practice of the People's Republic of China', Dalhousie Law Journal, 16(1):62.

Sampford, C., 1989. The Disorder of Law: a critique of legal theory, Basil Backwell Limited, Oxford.

Shaw, M., 1997. International Law, Fourth edition, Cambridge University Press, Cambridge.

Shearer, I.A., 1994. Starke's International Law, Eleventh edition, Butterworths, London.

$\mathrm{Vu}$ Duc Long, forthcoming. 'Status in the hierarchy of international treaties in Vietnam's legal system'.

Vu Thu Hanh and Alan Khee Jin, 1998. 'Country reports-Vietnam', Asia Pacific Journal of Environmental Law, 28:326. 